\title{
PSA Level Ten to Fifteen
}

National Cancer Institute

\section{Source}

National Cancer Institute. PSA Level Ten to Fifteen. NCI Thesaurus. Code C142106.

A blood concentration of prostate specific antigen between $10 \mathrm{ng} / \mathrm{mL}$ and $15 \mathrm{ng} / \mathrm{mL}$. 